lismus, i ten, který reálně fungoval či stále ještě existuje, je mnohem lepší. Podle mého názoru by jeho knize prospělo explicitní srovnání obou systémů, nikoliv jen analýza záporů kapitalismu.

Schweickart navrhuje zachování demokratického rozhodování a ústavní svobody. Přesto u mě vyvolal řadu pochybností: Co když se při pokusu o jeho realizaci objeví problémy a výrazný odpor, např. ze strany konzervativních skupin, které budou požadovat návrat kapitalismu, budou chtít šírit své „reakční“ názory? Omezí se svoboda slova, aby se jim zabránilo narušovat legitimitu nového systému? Budou tito jedinci trestáni? A co když se některým lidem nebude chtít $\mathrm{v}$ takových státech žít a odcházeli by? Bude se jim v tom po odchodu určitého procenta obyvatel bránit? Uzavřou se hranice? Nelze předem říci, jakou tendenci by lidské jednání mohlo mít. Je jeden člověk vůbec schopen domyslet, co se může stát, když má být změněna struktura společnosti? Co se stane při změně systému, který měl určitou míru legitimity, a když se určité skupině obyvatel odebere velký majetek? Je možné provést relativně radikální změnu a garantovat přitom svobodu? V jakém rozsahu ji bude nutno omezit? Pokud budou moci existovat politické strany, budou povoleny i takové, které reprezentují zájmy prŕznivců kapitalismu? A co když se z nějakého důvodu objeví vlna nespokojenosti s vývojem a lidem se nebude líbit nový řád? Bude i potom svoboda?

A můžeme si představit svět, kde je pro všechny lidi práce? Není to nereálné v situaci, kdy moderní technologie usnadňují a nahrazují stále větší část lidské práce? Nevyžadovalo by to zastavit vývoj moderních technologií? Stejně tak vyvolává pochybnosti, zda by bylo možno snadno odebrat bohatým vlastníkům jejich majetek. Schweickart jim připisuje např. schopnost udržovat uměle nezaměstnanost, podporovat rasismus (164-165), využívat válku pro své cíle (174-175), ukončit nepohodlný režim apod. Je možné takového soupeře přemoci, zvláště pokud má moc podle svých potřeb ovlivňovat veřejné mínění a bránit výraznější kritice, aby se stala významnou? A stojí skutečně jen malá skupinka bohatých vlastníků proti zbytku společnosti? Dělí se společnost jen takto? Není možno najít i jiné rozpory?

Kromě výše uvedených nejasností uvedených by bylo možno jmenovat řadu dalších problematických míst knihy (např. bude socialismus výrazně odlišný ve svém vztahu k životnímu prostředí, bude schopen zabránit velkému vyčerpávání zdrojů; pojetí politických stran a jejich funkcí v demokratických státech, viz 173-174). I přes výše naznačené problémy a jednostrannosti můžeme tuto knihu chápat jako inspirativní zdroj pro naše úvahy o povaze současného politického a ekonomického systému.

Josef Koudelka

Fakulta sociálních studií Masarykovy univerzity

\section{Kissinger, Henry:}

\section{ON CHINA}

New York: Penguin Books. 2011. 608 stran.

DOI: 10.5817/PC2013-1-109

S postupom času, ako si svet uvedomuje rast dôležitosti Číny, sa pulty kníhkupectiev plnia literatúrou „letiskového typu“, ktorá ponúka „,vyčerpávajúci“ výklad Č́ny a pokrýva „Všetko“, čo človek ,potrebuje“ o tejto krajine vediet'. Recenzovaná kniha $\mathrm{v}$ princípe ponúka podobné dielo, vysvetl'ujúce všetko „o Číne“ (ako už názov napovedá) a jej vzt'ahu so zahraničím. To, čo ju robí absolútne unikátnou, je jej autor. Henry Kissinger, 
poradca pre bezpečnost' a minister zahraničných vecí $\mathrm{v}$ administratívach prezidentov Richarda Nixona a Geralda Forda, bol práve tým, kto zahájil normalizáciu čínsko-amerických vzt’ahov a nastavil základné parametre ich bilaterálnych vzt'ahov. Kým v čase, ked' bola svetu oznámená návšteva prezidenta Spojených štátov v komunistickej Č́ne, sa jednalo o absolútnu senzáciu, táto udalost' s odstupom takmer polstoročia nestráca na dôležitosti ako mnohé iné „,senzácie“ - práve naopak. Diplomatické vzt'ahy USA-Č́na sa odvtedy rozvinuli do pravdepodobne najdôležitejšieho bilaterálneho vzt'ahu dvoch štátov na svete a do dnes čerpajú vo vel'kej miere $\mathrm{z}$ princípov definovaných počas počiatočných stretnutí, čo je skutočnost', ktorú autor $\mathrm{v}$ priebehu knihu na viacerých miestach pripomína. Predkladaná kniha od Henryho Kissingera je preto dlho očakávaným pokračovaním jeho publikačného diela, v ktorom sa venuje práve téme, ktorá sa dnes zdá byt' hlavným dedičstvo tohto významného štátnika.

Kniha On China má vyše 500 strán a obsahuje 18 kapitol, krátky predslov a úvod a rozšírený epilóg. Každá kapitola do určitej miery predkladá samostatný výklad určitej témy, ktoré sú celkovo radené chronologicky, s výnimkou prvej kapitoly a epilógu. V prvej autor prezentuje svoje pochopenie čínskej tradície, kultúry a spôsobu myslenia a tieto poznatky následne využíva $\mathrm{v}$ priebehu celej knihy. V epilógu sa zamýšl'a nad možnost'ami čínskeho mierového rastu a budúcnost'ou medzinárodného systému. Zvyšné kapitoly môžeme pomyselne rozdelit' do štyroch tematických častí. V prvej časti sa autor venuje histórii do roku 1949, témou druhej časti sú prvé dve dekády komunistickej republiky, na ktoré plynule nadväzuje podrobným popisom samotného nadviazania vzt'ahov medzi Č́nskou l'udovou republikou a Spojenými štátmi, ktorú budeme považovat' za tretiu čast' knihy. Štvrtá tematická čast' sa potom venuje historickému vývoju po Maovej smrti až po súčasnost'. Celkovo je možné konštatovat', že na rozdiel od mnohých podobných kníh o Číne, sa táto v rozhodujúcej miere venuje práve historickým udalostiam okolo zahájenia diplomatických stykov medzi USA a Č́nou. Z celkových 18 kapitol tak iba dve pripadajú na vývoj do roku 1949 a zhodne po jednej kapitole pre obdobie administra-

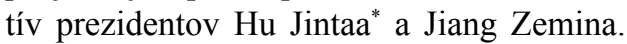
Takéto rozvrstvenie kapitol je pomerne pochopitel'né s ohl'adom na postavenie autora a práve opis okolností nadväzovania kontaktov s čínskymi lídrami patrí medzi najzaujímavejšie časti knihy, ked' sa autor obšírne vyjadruje o priebehu konkrétnych jednaní s Mao Zedongom, Zhou Enlaiom a neskôr s Deng Xiaopingom a Jiang Zeminom (s ktorými už jedná ako súkromná osoba a nie ako oficiálny predstavitel' vlády).

Hlavným ciel'om knihy, tak ako je definovaný autorom $\mathrm{v}$ predslove, je predstavit' čínsky spôsob myslenia o (zahraničnej) politike a na základe toho sa snažit' pochopit' kroky, ktoré čínski predstavitelia robili od vzniku Čínskej l'udovej republiky. Pre naplnenie tohto ciel'u je podstatná prvá kapitola, $\mathrm{v}$ ktorej autor definuje niekol'ko konceptov umožňujúcich, podl'a jeho názoru, komplexné pochopenie čínskeho zahranično-politického myslenia. Kissinger postupne predstavuje tradičné čínske vnímanie svojej krajiny ako od večných vekov existujúcej jednotnej entity, stojacej na konfuciánskych základoch, ktorá sa vníma ako vrchol civilizácie a formálne jej patrí celý svet. Špeciálnu pozornost' si zasluhuje prezentovaný spôsob myslenia plynúci zo strategickej hry weiqi (Go), ktorú Kissinger nazýva „najtrvanlivejšou“ (enduring) čínskou hrou. Kissinger poukazuje na kontrast medzi weiqi a šachom (ktorý vníma ako charakteristický pre západný spôsob myslenia) v preferencii absolútneho a roz-

\footnotetext{
*V texte bude použitý prepis čínskych mien a názvov podl'a spôsobu pinyin. Mená a názvy budú skloňované v súlade so slovenskou gramatikou.
} 
hodného vít’azstva $\mathrm{v}$ prípade šachu oproti súboju na viacerých frontoch postavenom na obkolesovaní, prevažovaní a získavaním relatívnej výhody v prípade weiqi. Pre pochopenie d'alších kapitol knihy je tiež významný tradičný čínsky spôsob externého zabezpečenia ríše, ktorý Kissinger predstavuje pomocou zložitých nevojenských prostriedkov ako podplácanie, rozdávanie titulov, projekcia kultúrnej soft power, využívania konfliktov medzi „,barbarmi“ navzájom, tak aby neboli schopní koordinovaného útoku na Č́nu.

Podrobný rozbor tejto kapitoly je vhodnou príležitost'ou ako poukázat' na niektoré nedostatky, ktoré kniha On China v sebe nesie. Práca s konceptom strategického myslenia na spôsob hry weiqi demonštruje spôsob, akým si Kissinger na niektorých miestach nepatrične zjednodušuje skutočnost'. Kým táto hra skutočne je čínska tradičná hra a je možné, že vzorce jej myslenia sú súčast'ou myslenia čínskych štátnych predstavitel'ov, prakticky to isté sa dá povedat' aj o verzii čínskeho šachu (xiangqi), ktorý stojí s minimálnymi obmenami na rovnakých základoch, aké Kissinger nachádza u západného šachu a v Číne bol prítomný po približne rovnakú dobu ako hra weiqi a teší sa minimálne rovnakej popularite. Elegantné vysvetlenie viacerých situácii z modernej doby tak do určitej miery stráca svoju brilantnost' tým, že Kissinger nevysvetl'uje, prečo práve weiqi má reprezentovat' spôsob čínskeho strategického myslenia a nie čínska verzia šachu. Navyše, na viacerých miestach $\mathrm{v}$ texte sa potom zdá, že Kissinger používa koncept weiqi ako synonymum pre klasickú mocenskú politiku, ked' napríklad Čína podl'a neho hrala weiqi $\mathrm{v}$ prípade himalájskeho konfliktu v roku 1962 s Indiou, podobne ako hrala weiqi v Taiwanských krízach. Tým sa opät' vnucuje otázka, do akej miery je aplikácia myslenia weiqi skutočne odlišná od tej potenciálne inšpirovanej šachom a čo to potom má znamenat' v praktickej politike.
Značné zjednodušenie, a do určitej miery nekonzistentné vysvetlenie, prezentuje Kissinger pri vel'mi stručnom prezentovaní vývoja centralizovanej čínskej ríše. Kissinger na jednej strane cituje známy začiatok klasického románu Príbehy troch riśsi o striedaní obdobia centralizácie a fragmentácie, na druhej strane však píše, že od roku 221 p. n. 1. prakticky prevládla idea centralizovanej ríše, aj napriek tomu, že niekedy obdobie decentralizácie trvalo aj „niekol'ko storočí“. Je možné takto jednoducho vyhlásit' dedičstvo centralizovanej ríše za prevládajúce a niekol'ko storoči decentralizácie za prechodné? Letmý pohl'ad na časovú osu znázorňujúcu čínske historické obdobia a dynastie musí velit' $\mathrm{k}$ opatrnosti - nachádza sa $\mathrm{v}$ ňom príliš vel'a paralelných dynastií, rozdrobených období a úspešných externých vpádov na to, aby bolo možné verit' tomu, že to bolo také jednoduché, ako hovorí Kissinger. Pre znázornenie komplexnosti východoázijského medzinárodného systému môže vel'mi dobre poslúžit' kniha od Wontacka Honga (2010) East Asian History: A Tripolar Approach.

Ďalšia rozporuplnost' tejto časti je aj prezentácia tradičného čínskeho vnímania sveta podl'a konceptu tianxia, kde Kissinger vysvetl'uje, že jeho doslovná aplikácia vlastne znamená, že čínsky cisár predstavuje vrchol svetovej civilizácie, a teda formálne neexistuje žiadne ,zahraničie“. Na druhej strane sa dočítame, že čínske teritoriálne ambície končili na mori a Č́na nemala žiadny záujem expandovat'. Mohla by sa vynorit' otázka - ak sú prezentované dve protichodné vnímania sveta bez toho, aby boli jasne zasadené do kontextu, má potom ich aplikácia na rozličné situácie nejakú výpovednú hodnotu? $\mathrm{Na}$ tomto mieste by sa opät' dalo konštatovat', že Kissinger prílišne zjednodušuje a odkázat'sa dá na literatúru, ktorá sa venuje téme čínskeho tradičného hierarchického vnímania sveta (vid' napr. Zheng 2010).

Dve kapitoly, ktoré Kissinger venoval udalostiam do roku 1949, začínajú popisom 
prvých kontaktov európskych vel'vyslancov k čínskemu cisárskemu dvoru, pokračujú cez postupné presadenie európskej moci počas Ópiových vojen a vnútenie tzv. nerovných zmlúv a končia obdobím nacionalistickej republiky. Je zbytočné rozvádzat' to, že vyčerpávajúci opis týchto udalostí by si vyžiadal podstatne viac priestoru ako ten, ktorý mu venuje autor knihy. Napriek tomu sa autor možno trochu prekvapujúco zameral $\mathrm{v}$ danom období na vývoj v 19. storočí a vývoj od začiatku 20. storočia až po koniec čínskej občianskej vojny prechádza iba na niekol'kých stranách. Prakticky vôbec sa napríklad nevenuje otázkam japonskej okupácii a čínskej občianskej vojny, čo je trochu zarážajúce, nakol'ko otázka Taiwanu je následne jedným z rozhodujúcich elementov čínsko-amerických vzt'ahoch a podobne otázka druhej čínsko-japonskej vojny zohráva dôležitú úlohu pri kultúrnom vysvetlení čínskej zahraničnej politiky, ktorú sa Kissinger v knihe snaží prezentovat'.

V súlade so štruktúrou knihy sa presuňme skokom do doby Maovej zahraničnej politiky, čím sa pomaly dostávame k obdobiu, ku ktorému má Kissinger povedat' naozaj vel'a. Kissinger sa v priebehu viacerých kapitol venuje najmä čínskemu angažmá v Kórejskej vojne, dvom Taiwanským krízam, vojenskému konfliktu s Indiou v roku 1962 a postupnému rastu napätia so Sovietskym zväzom. Č́nsku asertívnu politiku vysvetl'uje tradičnou taktikou tzv. prázdneho mesta, kedy sa velitel' mesta s minimálnou obranou pred prichádzajúcou presilou správa, ako by mu nehrozilo žiadne nebezpečenstvo, čím dosiahne odchod protivníkovej armády. Kissinger ukazuje, že Maov prezentovaný postoj o čínskej nedotknutel'nosti voči akémukol'vek rozsahu škôd bol v skutočnosti aplikácia tejto tradičnej taktiky a Maove zahranično-politické kroky sú následne opisované ako premyslené t’ahy, ktoré vždy priniesli svoj žiadaný úžitok, aj ked' často až z dlhodobého hl'adiska.
Samotná tretia tematická čast', a do vel'kej miery aj štvrtá, značne čerpajú z prepisov a dojmov autora $z$ jeho rozhovorov s vrcholnými čínskymi predstavitel'mi. Jedná sa samozrejme o nosnú čast' knihy, ktorá na mnohých miestach odkrýva detaily dôležitých politických rozhodnutí a ako taká predstavuje jedinečné primárne informácie o konkrétnych zlomových udalostiach. Kissingerové vnímanie nám na týchto miestach môže byt' sympatické, alebo nie, jedná sa však $\mathrm{v}$ princípe o reálny opis konania jednotlivých aktérov, s ktorým sa dá polemizovat' nie na základe pravdivosti, ale normatívnosti. Práve $\mathrm{v}$ týchto miestach sa stáva najviditel'nejším osobné presvedčenie autora, ktoré môžu byt' mnohými považované za prílišne nekritické vo vzt'ahu k Číne. Autor nijako neskrýva svoj obdiv k čínskemu l'udu, ktorý sa miestami stáva mierne patetickým, napríklad ked' ho obdivuje za svoju húževnatost', s ktorou sa dokázal vysporiadat' so všetkými katastrofami moderných dejín. Autor sa v prevažujúcej miere vyjadruje pozitívne aj o všetkých vrcholných lídroch $\mathrm{s}$ ktorými mal do činenie a $\mathrm{z}$ jeho rozprávania sa dá vyčítat' uspokojenie nad ich „realistickým“ uvažovaním $\mathrm{v}$ rámci medzinárodných vzt’ahov. $\mathrm{V}$ priebehu celej knihy sa dá nájst' iba niekol'ko situácií, kedy Kissinger naznačil kritický postoj, jeho prístup je však v prevažujúcej miere odlišný a pri každej diskutovanej udalosti diskutuje skôr dôvody, pre ktoré čínski lídri konali tak ako konali a neposudzuje racionalitu týchto krokov, respektíve ich kroky považuje implicitne za racionálne. Týmto spôsobom sa vyjadruje okrem všetkých vojenských konfliktoch, v ktorých podl'a neho Čína vždy dosiahla svoj ciel', aj o niektorých problematických vnútropolitických udalostiach. Kultúrna revolúcia tak podl'a neho mohla pripravit' cestu pre nasledujúce Dengove reformy a udalosti z roku 1989 na námestí Tiananmen boli nešt'astnou zhodou okolností a najdôležitejším bolo pokračovanie reformného procesu zahájeného 
Dengom. Kissinger je naozaj neodškriepitel'ným zástancom klasického realistického uvažovania, ked' sa na viacerých miestach zdá, že verejnú mienku vníma ako nevhodne limitujúci faktor diplomata, ktorý vie sám čo je potrebné a snaží sa o dosiahnutie konečného dobra. Táto Kissingerova pozícia rozhodne nie je prekvapujúca a nová, avšak počas diskusií o udalostiach, ktoré stáli životy mnohých l'udí je trochu zarážajúca. Toto je najlepšie viditel'né počas jeho opisu jednania $\mathrm{s}$ Dengom a Jiangom tesne po udalostiach zo 4.6.1989, kedy sa Kissinger a aj prezident Bush pri svojej komunikácii de facto ospravedlňujú čínskym predstavitel'om za to, že musia verejne zaujat' kritické stanovisko, ktoré je dôsledkom tlaku verejnej mienky. Počas jednania s Maom sa zase čitatel' môže zamysliet' nad tým, o čo „lepšia“ bola zahraničná politika demokratických Spojených štátov od komunistickej Číny, ked' podl'a Kissingerovho opisu sa zdá, že si štátnici rozumeli výborne a sledovali miestami zhodné zahranično-politické direktívy, ktoré sa zhodne snažili presadit' vo svojom vnútropolitickom prostredí.

Ako sa Kissinger dostáva $\mathrm{k}$ súčasnosti, vracia sa $k$ analýze všeobecnej situácie a opúšt’a opisy zákulisných jednaní s čínskymi predstavitel'mi. Obmedzený priestor však znamená, že sa zd’aleka nedostane na všetko. 90. roky sú diskutované z pohl'adu vzt'ahov USA-Č́na najmä na pozadí dedičstva roku 1989 a d'alších udalostí, ktoré priniesli tretia Taiwanská kríza, bombardovanie čínskeho vel'vyslanectva v Belehrade a zostrelenie americkej špionážnej stíhačky nad ostrovom Hainan. V novom miléniu je zase prevažujúcou témou čínske vnímanie zahraničnej politiky a autor diskutuje rast nacionalizmu, ktorý vníma ako potenciálny problém pre zahraničnú politiku. Opät' by sa dalo povedat', že Kissinger vynecháva problematické témy zahraničných vzt'ahov Č́ny, napríklad sa iba vel'mi heslovite vyjadruje o podhodnotenej čínskej mene a problematických ekonomic- kých vzt'ahoch, nediskutuje rolu vlády pri podpore nacionalizmu ako vlastného legitimizujúceho prvku, úplne vynecháva regionálne vzt'ahy a teritoriálne konflikty vo Východočínskom a Juhočínskom mori, problematiku l'udských práv, vnútorné čínske problémy a podobne.

Je samozrejme pochopitel'né, že autor bol nútený vybrat' $\mathrm{z}$ množstva tém, ktorým sa bude venovat', tlačí sa však na mysel' otázka, či jeho obraz, ktorý prezentuje, nie je príliš nachýlený $\mathrm{k}$ optimistickému vnímaniu situácie. Je možné, že Kissinger sa pod vplyvom svojho postavenia, ktoré v Č́ne má, zdráha kritizovat' a prezentovat' negatívne scenáre? Prípadne, je možné, že súkromné záujmy, plynúce zo záujmov jeho konzultatívnej spoločnosti Kissinger Associates, mu znemožňujú otvárat' niektoré témy? Odpoved' na tieto otázky si bude musiet' urobit' každý čitatel'. Pravdou je, že v epilógu Kissinger niektoré problematické momenty naznačuje a na pozadí porovnania rastu Nemecka pred prvou svetovou vojnou diskutuje možnosti čínskeho rastu. Po stručnej prezentácii témy však autor nepokračuje v jej d'alšej analýze, ale miesto toho zakončuje knihu volaním po vytvorení „Pacifického spoločenstva“, ktoré by zabezpečilo jednotný rámec mierového riešenia problémov a koordinovania politík $\mathrm{v}$ priestore Tichého oceánu.

Na záver je možno prijat' názor, že kniha neponúka vyčerpávajúcu prácu „o Číne“, tak ako by sa mohlo zdat' z jej názvu. Kniha nemá atribúty striktne vedeckej „,neutrality“, ale $\mathrm{v}$ prvom rade predkladá opis historických udalostí, ktorých svedkom bol jeden z najvýznamnejších amerických diplomatov 20. storočia a $\mathrm{v}$ druhom rade potom prezentuje jeho vnímanie historického kontextu a dopadov sledovaných udalostí na súčasný a budúci vývoj vzt’ahov Číny so zahraničím. Selektívny výber diskutovaných udalostí však nie je úplne bezproblémový a navyše autor na niektorých miestach volí problematický spôsob prezentovania niektorých historických 
skutočností. Pre čitatel'a, ktorý sa v čínskych reáliách príliš nevyzná, môže tento postup znamenat' vytvorenie skresleného vnímania, prípadne predčasného optimizmu o ,pochopení“ čínskeho strategického myslenia. Čerstvým nadšencom pre Čínu je v tomto prípade možné odporučit' štúdium textov venujúcim sa modernej histórii Č́ny s o niečo viac komplexným spôsobom (vid' napr. Fenby 2008, Fewsmith 2008 a d'alšie). Pre čitatel'ov $\mathrm{s}$ určitými vedomost'ami o čínskych reáliách naopak kniha ponúka neocenitel'ný zdroj materiálu v surovej podobe, a okrem toho ambiciózny projekt vysvetlenia motivácie čínskej zahraničnej politiky, ktorý sám o sebe pôsobí vel'mi stimulujúco na zaujatie vlastného stanoviska. Z týchto dôvodov je táto kniha vel'mi cenným a odporúčaným materiálom.

\section{Použité zdroje:}

Hong, Wontack. 2010. East Asian History: A Tripolar Approach. Seoul: Kudera International.

Fenby, Jonathan. 2008. Modern China: The Fall and Rise of a Great Power, 1850 to the Present. New York: Harper Collins Publishers.

Fewsmith, Joseph. 2008. China Since Tiananmen. From Deng Xiaoping to Hu Jintao. Cambridge: Cambridge University Press.

Zheng, Yongnian, ed. 2010. China and International Relations: The Chinese View and the Contribution of Wang Gungwu. New York: Routledge.

Richard Turcsányi

Fakulta sociálních studii Masarykovy univerzity 